\title{
The Evolution of Cooperative Legislation in Cameroon
}

\author{
By Godfred A. E. Penn and Wawa A. Ngenge
}

\section{Introduction}

It is a perceptible phenomenon in Cameroon today that the welf are state has envolved. This is evident in the fact that the economic situation in the country is characterised by stagnation in traditional agriculture crops, lack of competitiveness in manufacturing, an illiquid financial sector, and inefficiency in many public and parastatal enterprises. Beginning in the 1987/88 fiscal year, the government launched an austerity programme aimed at reducing its budgetary deficit. This was followed by a stabilization programme supported by an IMF standby arrangement, the main components of which are: restructuring the parastatal sector, reducing intemal marketing costs for major traditional agricultural exports while creating a more liberal marketing environment, reforming industrial and commercial incentives to reinvigorate these highly protected sectors, as well as revitalising the banking sector through regulatory and institutional reforms and recapitilisation.

In spite of these measures, today, Cameroon's adjustment process remains slow and stabilising the decline in per capita income remains an elusive goal. However, what remains a concrete and perceptible fact is that along with the disappearance of the welfare state has arisen the desire to reorient the philosophy of economic development in Cameroon. One of the ways in which this desire has been expressed is the establishment of a legal framework conducive to the creation of a variety of economic groups 1 in order to provide adequate support for development actions of all types undertaken by private operators in all economic sectors. In the domain of cooperatives, this manifested its most concrete expression in the Declaration of Govemment Policy on Co-operative Societies and other Economic Interest Groups which was signed by the Minister of Agriculture on January 28, 1991. In the preamble of that Declaration, one of the priority objectives of govemment was stated as being the promotion of more active and better participation by urban and nural people alike in the economic development of the country. This could be achieved through the integration into the government's development strategy of measures which allow the further develop-

1 Some of these economic groups include Cooperative Societies, Common Initiative Groups, and their Unions, the creation and management of which is now govemed by law No. 92/006 of August 14, 1992 and its Decree of Application No. 92/455/PM of November 23, 1992; and the law on the so-called "Groupements d'Intérêt Economique" which is still in the pipeline. This is in fact the equivalent of the Partnership Laws of former West Cameroon, which are still in force and are not repealed by the new text. 
ment of the private sector, and especially co-operative societies and other economic groups. 2 Consequently, the govemment's role was seen as one of facilitating the creation of cooperatives and other economic groups. This was to be done principally by providing a legal, regulatory, economic and political environment that would enhance their development. Consequently, a clear need was seen for the enactment of new legislation that would integrate the new elements of liberalisation which condition the development of cooperatives and economic groups by permitting them to function as private enterprises under the control of their members and elected representatives.

Most of that new legislation is now in place and the aim of this article is to trace the development of legislation goveming cooperative societies in Cameroon. The article stars off in part one by reviewing cooperative legislation in Cameroon during the colonial period. Part two reviews the attempt at unification of cooperative legislation and what impact that has had on the perception of the role of members and that of govemment in cooperative societies today. Part three reviews the new legislation from the inception of the draft following the Policy Declaration to the promulgation of the law in 1992. In highlights positive aspects as well as shortcomings and potential problems. The conclusion looks at the future of cooperatives within the context of Cameroonian economic reform as a whole.

\section{Cooperative Legislation during the British and French Mandates}

\section{Cooperative Legislation in French Caneroon}

The first co-operative legislation in French-speaking Cameroon seems to be traceable to 1937.3 In that year, authority was given to the Commissioner of Cameroon under French Mandate to make decisions creating what in effect amounted to indigenous self-help and agricultural mutual credit cooperative societies. ${ }^{4}$ The three main aims assigned to such cooperatives were:

2 Economic Groups were defined in that Declaration as being all types of organisations needed by people for economic ends, having need for legal personality, not registered as a couperative society or commercial company and allowing each of its members to take individual advantage of collective activities.

3 See Décret du 7 juin 1937 portant création au Cameroun des sociétés indigènes de prévoyance, de secours et de prêts mutuels agricoles (J.O.C. 1937, p. 577). The first cooperative society in the former East Cameroon seems to have been established in 1926, when Marchand was the High Commissioner, "La Cooṕrative d'Achat en Cornmun des Machines Agricoles pour le Groupement Eton-Est de la Région du Nyong et Sanaga". For more on the historical development of cooperatives in French-speaking Cameroon, see Soho, A., Le Role du Secteur Coopératif dans le Financement du Développement Agricole au Cameroun, unpublished Doctorat de Troisième Cycle Thesis, University of Yaounde (1983-84), pp. 26 et seq.

4 Déctet du 7 Juin 1937, Article 1. 
a) to take all measures which could contribute to the development of agriculture, animal husbandry, fishing, harvesting, handling, processing, transporting, conserving and selling produce by helping their members organise such activities;

b) to come to the aid of needy members either by giving them temporary help or loans;

c) to help their members to develop, ameliorate and maintain their farms through loans in kind or in money. 5

Furthermore, they could make loans to other such self-help societies as well as other organisations permitted under the decree, on condition that they were also composed of members of the society only. 6 They could also constitute a common fund with a legal personality whose organisation and attributes could be determined by decision of the Commissioner of the Republic or they could group thernselves into unions under like conditions. 7 But the creation of such indigenous societies was limited to one per administrative sub-division. This sub-division was defined as the smallest unit under a European's command but a society created therein could be divided or split according to territorial divisions or ethnic groupings. 8 Apart from this discriminatory criterion and the fact that membership was obligatory for every indigenous or local farmer9 and breeder from the region, contributions for membership and debt reimbursements were recovered in the same manner as taxes. Furthermore, the founding members upon creation of a society were required to send to the Commissioner of the Republic draft bye-laws which the Commissioner. The bye-laws could only come into force if they were approved by a decision of the Commissioner declaring their conformity with the provisions of the Decree.10 Once the bye-laws were approved the cooperative society would have a legal personalityll but the bye-laws could only be amended following the same conditions under which they were originally approved.12 Also administration was entrusted ex-officio to the colonial administrator of the region who assumed the functions of Chairman of the Board of Directors 13 and who was entitled to send to the Commissioner of the Republic an annual report on the moral and financial situation of the cooperative society. 14

5 Id. Aricle 2.

6 Id.

7 Id.

8 Id. Article 3.

9 Id. Article 4 and further stressed in Article 1 of Arrêté du 9 juillet 1937 fixant les conditions d'application du decret du 7 juin 1937 instituant des sociétés indigènes de prévoyance, de secours et de prêts mutuels agricoles (J.O.C. 1937, p. 590).

10 See Decree of 1937, supra, Article 7.

11 Id. Article 9.

12 Id. Article 8.

13 Id. Article 5.

14 Id. Article 11. 
Other members of the Board of Directors were elected for three-year terms in accordance with local customs and their mandates could be renewed indefinitely. 15 Management was then entrusted into the hands of one or more people chosen by the administrator of the region from among personnel of the agricultural or veterinary services, with a secretarytreasuret being chosen from the special or intennediate level workers at the headquarters of the cooperative society. 16 Since these were essentially agricultural cooperatives, they were required in their financial management to be excessively prudent ${ }^{17}$, only making one of three types of specified borrowings to members 18 , and even taking out insurance policies against such things as animal mortality, agricultural hazards such as fire, floods, drought and other kinds of work accidents. 19

Eventually, another text of 194420 was promulgated in relation to information cooperative societies but did not apply to Cameroon since it specifically provided that it applied only to Algeria and the French Colonies.21 Subsequently, however, a law of September 10, 194722 was passed which defined cooperatives as organisations having essentially two objectives and whose business could be carried out in all fields of human activity. 23 One remarkable characteristic of this law was that it was more liberal in the conditions it imposed on the formation, organisation and administration of cooperative societies. Apart from allowing them to exist in all branches of human activity rather than just agriculture and animal breeding, this law provided that they could be administered by representatives appointed for periods not exceeding six years by the general meeting which alone could revoke them 24 , and their bye-laws were no longer subject to approval by the Commissioner of the Republic as was the case under the June 7, 1937 Decree.25

Unfortunately, and apparently due to the beginning of political activism in French Cameroon, this rather liberal law was short-lived. For this reason, all of its provisions except Article 24 which dealt with the protection of the term "cooperative" were repealed

15 See Arrêté op cit. note 9, Article 5.

16 Id. Article 6.

17 Id. Article 11.

18 Id. Article 14

19 Id. Article 16.

20 Ordonnance du 27 juillet 1944 relative aux coopératives d'information (J.O.C. 1944, p. 568).

21 It is to be noted that at this point in time, East Cameroon was a mandate territory under French administration.

22 Loi du 10 septembre 1947 portant statut de la coopération.

23 Id. Article 1.

24 Id. Article 6.

25 However, this liberty was later restricted in an Arêté du 10 juin 1949 fixant les modalités du contrôle des coopératives au Cameroun (J.O.C. 1949, p. 758). 
by a Decree of February 2, $1955 .^{26}$ If that Decree can ben criticized for its vagueness in the definition of cooperatives and their unions 27 , it seems to have maintained some of the liberalism of the law of 1947 by allowing the Board of Directors to be appointed by the General Meeting.28 Even in this regard, cerain eligibility conditions were imposed on persons willing to be members of the Board of Directors.29

Moreover, the legislation was more precise as to how a cooperative society could be formed. It is thus that it provided that the intention of creating a cooperativ society was to be manifested in a formal agreement signed by seven members at least. This declaration should contain not only the name of the cooperative but also its objects and head office and had to be sent to the technical assistance service for cooperatives. Its Signatories also had to indicate the date and place of the constitutive General Meeting during which the bye-laws of the cooperative society would be approved, its Board of Directors designated, the list of subscribers to its initial share capital established, and the first payments made in view of constituting the share capital.30 Furthermore, the Decree clearly stated conditions that had to be fulfilled in order to obtain a certificate of registration and even provided that if the licensing committee did not act within a certain time-limit the cooperative society would be presumed to have been effectively licensed 31 and the technical assistance service could then proceed to ensuring its registration and fulfilling the publicity and registration requirements provided by another decree. 32 Once registered, the Board of Directors could appoint a manager for the cooperative society who could not himself be a member of the Board if he was a member of the cooperative. He was then to carry out his duties under the control of the Board but could not be allowed to manage the cooperative if he directly or indirectly was involved in commercial and industrial activities or had been subject to any of the restrictions imposed by a Decree of September 3, 1936.33

These provisions as well as others in the Decree laid down an important foundation for the later development of Cooperative Law in Cameroon, especially in the recent legislation of 1992. For example, Article 23 of the Decree introduced a principle with regard to guardian-

26 See Décret du 2 février 1955 portant statut de la coopération dans les territoires relevant du Ministre de la France d'Outre-mer (J.O.C. 1955, p. 412).

27 See Id. Article 2 which simply stated "les coopératives et leurs unions sont des sociétés civiles particulières de personnes, à capital et personnel variables".

28 Id. Article 13.

29 Board members had to be citizens of the French Union, except where special authorisation was granted by the licensing committee; enjoy full benefit of their civic rights; never having been to jail or prohibited from holding office nor exercise any activity directly or indirectly which was competitive with that of the cooperative. Id.

30 Id. Aricle 4.

31 Id. Aricle 5.

32 Id. Articles 6 and 28.

33 Id. Article 15. 
ship and control that was to be used in later legislation to stifle, rather than enchance, the development of cooperative societies. That Article provided that the French Govemor could decide on which administrative service in his territory he would designate to provide technical assistance to cooperatives. The mission assigned to this techmical assistance service was to promote the cooperative movement, to assure the expansion of the knowledge of cooperative principles and rules, to help cooperative socienies by drawing up model bye-laws, giving opinions and advice and controlling the creation, functioning and management of cooperative societies. But this control was subject to the caveat that once a Imion of cooperatives would have been established and possessed sufficient funds to be able to assume the functions of the technical assistance service in its paricular branch of activities, such functions would be transferred to it, on the advice of the licensing committee, by decision of the territorial head or colonial administrator. 34

Unfortunately this provision was employed in subsequent legislation in the former East Camerooon to create the Department of Cooperation and Mutuality which virtually became a guardian ad litem for Cooperative Societies, treating them much like children who should be subject to its every control. It is thus that Law No. 69//COR of December 6, 1969, on the status of cooperative societies in the former East Cameroon divulged important powers on the Department of Cooperation and Mutuality35 going as far as authorising it at any moment to order an inquiry into the formation, functioning and financial situation of cooperative societies. 36 Some of these powers were so exorbitant that the D-parment could, for example, order the ex officio dissolution of a cooperative society merely because it deemed it to have violated statutory, regulatory or legislative provisions, withouth further precision. 37 But Law No. 69/KCOR cannot only be viewed in terms of the negative contributions it made to the evolution of cooperative legislation in Cameroon. Apart from merely reproducing most of the positive aspects of the Decree of 195538, it provided some innovations of its own. One such innovation was the provision that given the status of cooperative societies as non-profit organisations acting in the interest, and for the benefit, of their members, they were granted special tax advantages provided for by the General Tax Code 39 or particular texts applicable to each of them.

34 Id. Aricle 23.

35 Loi No. 697/COR du 6 décembre 1969, Arricle 37 et seq. A similar organisation was created in 1949 but its powers were not so extensive. See Arrêté du 21 janvier 1949 portant réorganisation du contrôle des organismes coopératifs et des sociétés de prévoyance (J.O.C. 1949, p. 140).

36 Id. Article 41.

37 Id. Article 50 (1).

38 op. cit. supra note 26 . et seq.

39 See Article 2 of law No. 69/7COR; see also Article 2 of law No. 73/15 of December 7, 1973 and Article 77 of law No. 92/006 of August 14, 1992 which is more specific in this respect by providing for exoneration from company tax. 
This section of part one has made a very cursory attempt to review the evolution of cooperative legislation in French-speaking Cameroon prior to Re-unification with Englishspeaking Cameroon in 1972. One aspect that stands out from this review is that though the different pieces of legislation generally recognised that cooperative societies benefitted from a legal personality, there was no mention as to whether they were subject to limited liability or not. It is probably because of this that very little autonomy was allowed cooperatives by the state, especially under Law No. 697)COR. The most palpaple consequence of this was that even after Re-unification, when an attempt was made to unify the two legal regimes in Cameroon in this respect, these organizations were handicapped and, probably, even prevented from reaching their fill potential.

Before dealing with this in more detail40 later, it is pertinent here to look at the evolution of coperative legislation in English-speaking Cameroon.

\section{Cooperative Legislation in Cameroon under British Rule}

Prior to April 1, 1956, the law applicable to cooperative societies in the Cameroons under British Rule was the Cooperative Societies Ordinance41. The first thing to note about the Ordinance is that although it purported to apply to cooperative societies, the term was not defined in it. Rather, it merely contented itself with defining a registered society which for its purposes was deemed to be a cooperative society registered under the Ordinance. 42 But on April 1, 1956, this Ordinance was repealed by the Southem Cameroons Cooperative Societies Law 1955.43 Surprisingly, however, though the new legislation defined a cooperative society, that definition was quite vague. In effect, a cooperative society was merely defined under that statute as one which was registered in the Southern Cameroons or which was deemed to have been so registered under the provisions of the Cooperative Societies Ordinance or under the provisions of the law itself. It can be seen from th is vague definition that unlike in the French Cameroons where from the outset the legislator intended cooperative societies to operate in limited domains such as agriculture and animal husbandry44, there was probably an intention to be more liberal and allow cooperative societies in various other fields of human endeavour, especially marketing cooperatives.

The main characteristics of the statute were that it dealt successively with preliminary issues, the registration of cooperative societies, the duties and privileges of societies once

40 See Part Two inf ra and the notes accompanying it.

41 See the Cooperative Societies Ordinance, Cap. 39 of the 1948 Revised laws of the Federation of Nigeria and Lagos, vol. 1, pp. 522 et seq.

42 See Id. Section 2 which is the definitions section of the Ordinance.

43 Southem Cameroons Law N. 13 of 1955.

44 See supra note 4 and the text accompanying it. 
registered, the rights and liabilities of their members, the property and funds of registered societies, the audit, inspection of and inquiries concerning societies, political activities, the dissolution of cooperative societies, surcharges on or the attachment of the property of people who have fraudulently dealt with the property of a cooperative society, disputes, the division and amalgamation of societies, the making of regulations under the statute, and miscellaneous issues.

The qualifications for membership in cooperative societies were, in the case of a person, to have attained the age of eighteen and either be resident within the society's area of operation as described in its bye-laws or occupy land within it 45 , and in the case of being a member of another society, especially a secondary society, to have its registered address within the secondary society's area of operations and be holder of property within such area of operation. 46 But there was a provision in this second case for the Registrar of Cooperatives to grant exemption from qualification if the primary society was one with limited liability. 47 Furthermore, membership was subject to two other restrictions. First, a member could only exercise his rights as member of a cooperative society if he had made payment to it in respect of membership or acquired such other interest in it as was prescribed by the regulations or the bye-laws of that society. 48 Secondly, no person could be a member of more than one registered society whose primary object was the distribution of credit without the fiat of the Registrar of Cooperative Societies. 49 The purpose of these restrictions seems not to have been to limit the liberty that was inherent in the law in the formation of cooperative societies but to protect them against fraudulent activity.

Though with respect to the rights and liabilities of members the provisions of the Southem Cameroons Cooperative Societies Law were similar to those of the Cooperative Societies Ordinance from which it had been adopted, there were certain innovative features in the Law which did not exist in the Ordinance. One such innovative feature was the right of minority or under-age persons duly admitted as members of registered societies to enter into contracts with such societies or grant them acquittances. 50 Also, the liability of a past member for the debts of a registered society could subsist only for a period of two years from the date he ceased to be a member. And so would the liability of the estate of a deceased member. 51

45 This condition operated like the requirement to be a native of the region that we saw under the Decree of 1937 in French-speaking Cameroon.

46 Southem Cameroons Law Nr. 13 of 1955, Section 22 (1).

47 Id.

48 Id. Section 23.

49 Id. Section 24.

50 Id. Section 27. No similar provision existed in the Laws of French-speaking Cameroon discussed supra.

51 Id. Section 30 (1) and (2). 
A striking characteristic of the law was that at the discretion of the Registrar, a society whose object was the promotion of the economic interests of its members in accordance with cooperative principles or one established with the object of facilitating the operations of such a society could be registered with or without limited liability. 52 Moreover, no primary society could be registered if it did not have at least ten members qualified as required by the Law and no secondary society registered unless it had at least two registered societies as its members. 53 Furthermore, whereas the registered address of any society applying to be registered under the law was required to be situated in the Southem Cameroons, the word cooperative or its vemacular equivalent had perforce to form part of its name. And so did the word "limited" or its vernacular equivalent for societies with limited liability.

It ought to be remarked here that unlike their counterpars in French-speaking Cameroon54, cooperatives in Cameroon under British Rule were allowed to have limited liability. The consequence of this was that the registration of a society rendered it a body corporate with certain rights inherent in the possession of legal personality. These included perpetual succession, owning a common seal, the right to hold movable and immovable property of every description, to enter into contracts, to sue and be sued and to do all other such things that were necessary for its constitution.55 This in turn imposed some liabilites on it and gave the Registrar the powers not to control them but to audit or cause them to be audited by other persons, to inspect their books and require returns from them and to order inquiries and inspections. 56

Another striking characteristic of the statute was that just like in its contemporary in French Cameroon57, there was a noticeable aversion to political activity. It is thus that the Secretary of State had the powers to appoint a committee of inquiry where it appeared to him that an officer of a society was taking part in politics to the detriment of the society. He could even order the society in question to remove that officer from office or make an order for the cancellation of its registration where it failed to make such a removal. In either case, however, any aggrieved officer or society had the right to appeal to the High Court within one month from the date of such order and the decision of the High Court on it would be final.58 On the other hand, a general power was given to the Commissioner of the Cameroons to make all such regulations which in his opinion were necessary for the purpose of canying out or giving effect to the principles and provisions of the Law. In the

52 Id. Section 4 (1).

53 Id. Section 5 (1) and (2).

54 See supra pp. 2 et seq.

55 Southem Cameroons Law Nr. 13, 1955, Section 8.

56 Id. Part VI.

57 See the stringent provisions of the Decree of February 2, 1955 in this regand.

58 Southem Cameroons Law Nr. 13, 1955, Par VI A. 
case of certain very specific issues ${ }^{59}$, it was obligatory to make such regulations. It is in the implementation of this power that the Southem Cameroons Cooperative Societies Regulations of 1957 were made which, inter alia, regulated the transfer of shares, division of surplus 60 , the appointment of the chairman and election of committees, their removal from office, general meetings and voring therein, the amendment of the bye-laws, the appointment of a secretary by the committee, the disposal of finds on liquidation of a cooperative society, the fees payable for the inspection of records, etc. One commentator has even said that though the cooperative movement in the former West Cameroon had the particular characteristic of being monolithic and composed entirely of autonomous cooperatives administered by their members, the Registrar's duties were circumscribed to giving technical advice and seeing to it that legal provisions were properly followed.61 This assessment seems to be quite opposite.

The Law of 1955 and the Regulations of 1957 made thereunder were thus quite detailed and applied to cooperatives in the Southem Cameroons up to independence and, thereafter, in the former West Camenoon until after the unification of the two Federated States of Cameroon. It was not until 1973 that the National Assembly promulgated a new law attempling to unify the existing laws on cooperative socieives in West and East Cameroon. It was at that time that Southem Cameroons Law No. 13, 1955 and its East Cameroon counterpart Law No. 69//COR of December 6, 1969, were repealed.

\section{The Attempt to Unify Cooperative Legisiation Following the Re-unification of Cameroon}

Cameroon has in its short legal history faced difficulties in framing national laws because of its complicated colonial past which has made it subject to the influence of two potentially divergent foreign legal systems struggling for supremacy in determining not only the nature but also the content of its new uniformised national laws. 62 This is true of the attempt that was made in 1973 to unify cooperative legislation in Cameroon as well. Before this is expatiated on further, one clarification needs to be made as to why the former West Cameroon continued to apply a law adopted in this domain in 1955 though it achieved

59 Id. Section 54 (2).

60 Cooperaive societies being business organisations sui generis are not normally considered to be profit-making entivies. Thus any profits made by them are called surpluses and are exempt from company tax though when members receive dividends they are enlitled to pay tax on their incomes.

61 See Le Floch, Mouvements Coopératifs en Afrique Noire et Madagascar - Le Mouvement Coopéravifs au Cameroun, Bilan et Perspecrives, BDPA, Paris, 1964, at p. 14.

62 See also Fombad, C.M., The Scope for Uniformised National Laws in Dameroon, R.J.A. (1990) No. 3, p. 59. 
independence in 1961 while its conterpart Federated State of East Cameroon went through two pieces of legislation 63 of its own between independence in 1960 and 1973. This is because certain legislative provisions and especially the 1972 Constitution recognised the continuous applicability of all received foreign laws which had not been repealed or were not incompatible with the Constitution. 64

This clarification having been made, it is worth pointing out that Law No. 73/15 of December 7, 1973 which repealed the legal regimes prevalent in the former West and East Cameroons in cooperative matters envisaged a unified cooperative law for the United Republic of Cameroon that was never achieved. Instead, it clearly followed the regime which had been prevalent in the former East Cameroon since the Decree of 1955, characterised by a heavy intervention by the State based on the hypothesis that the population targeted by cooperative legislation was immature and needed nurturing. By so doing, it totally ignored the fact that cooperative societies are business organisations, sui generis, whose main objective is to promote the economic interests of their members on a self-help basis.65 Instead, it sought to preserve the notion prevalent during the French Colonial period that cooperatives were mainly instruments for increasing and improving the production of cash crops among progressive farmers, organising supplies and the marketing of products, distributing consumer goods and, to some extent, organising savings and credit distribution.66 This philosophy was preserved through the omnipresent and omnipotent authority exercised by the Ministry of Agriculture in every aspect of cooperaive life under the law from formation 67 through management 68 to possible transformations 69 and even going out of existence70. One curious consequence of this omnipotence and omnipresence of the guardian Ministry was that even if a cooperative society felt that it was incapable of continuing to cany out its business and wanted to voluntarily wind up, it could not do so without the fiat of the Ministry of Agriculture.71 This has led to a situation where there are

63 I aw No. 60/81 of December 31, 1960 completing law No. 59/48 of June 17, 1959 and law No. $697 /$ COR of December 6,1969, respectively.

64 See Article 38 (The Final Provisions) of the Constitution of 1972.

65 See in this regard Münkner, $\boldsymbol{H}$ H., Participative Law-Making: A New Approach to Drafting Cooperative Law in Developing Countries, paper presented at the Intemational Consultation on Innovaive Approaches for Cooperative Development in Asia, COADY International Institute, St Francis Xavier University, Antigonish, Nova Scotia, Canada, September 30 - October 11, 1985, at p. 2.

66 This logic seemsquite prevalent in the texts discussed under French-speaking Cameroon in Part I supra, ranging from the 1937 Decree through to the 1973 law.

67 See Law No. 73/15 of December 7, 1973 on the status of cooperative societies in Cameroon, Sections 5 and 10.

68 Id. Section $28,30,32,34$ and 36.

69 Id. Section $37 \mathrm{et}$ seq. conceming the constitution of reserves and utilization of funds, supervision and control, and amalgamation and division.

70 Id. Section 47 et seq.

71 Id. Section 48 (3). 
a lot of moribund cooperative societies existing in the country today which can do noting to help themselves other than accumulating debts and other obligations. Indeed recent attempts by certain cooperatives such as CAPLAMI72 and CAPLANOUN73 to distance themselves from UCCAO74 and reinvigorate themselves from an autonomous position seem to be viewed by the Ministry of Agriculture with suspicion. This was mainly because the underlying concept of the 1973 law was that cooperatives are tools of development which can be used by government to serve the public interest. The effect of this reasoning was two-fold. First, cooperative structures were created in accordance with administrative demarcations and jurisdictions. Second, government had the obligation to provide special services through public organisations such as COOPMUT75 and CENADEC76, which had to assist supervise, audit and virtually manage cooperatives.

One conclusion that can be drawn from the existence and the missions of these public services is that there was either profound reservation on the part of government about the wisdom of giving official legitimacy and encouragement to the cooperative movement which could easily be exploited for wanton political ends, or a dire need to control cooperative societies engaged in activities which created much value-added and resources which could be redeployed by govemment for other purposes. 77 Nevertheless, a logical consequence of the excessive intervention of the supervisory authorities under the 1973 law was that though on paper membership in cooperative societies was supposed to be voluntary, in practice this was meaningless. There were apparently two reasons for the disaffection of membership that has left the cooperative movement in Cameroon, under the $1973 \mathrm{Law}$, almost totally moribund today. On the one hand, the excessive intervention of government authorities led to the perception, even in the former West Cameroon where both producer and marketing cooperatives had flourished under the $1955 \mathrm{Law}$, that cooperatives were semi-public institutions and, therefore, a matter of government to be financed by government. On the other hand, even among people who were willing to be members, the fact that all members were treated in like manner irrespective of their individual contributions to the activities of the cooperative society led to the feeling in many that there was noting to gain or loose by being a member. Furthermore, even though the law provided that the appoint-

72 Coopérative Agricole des Planteurs de la Mifi, in the West Province.

73 Coopérative Agricole des Planteurs du Noun, in the West Province.

74 Union Centrale des Coopératives Agricoles de l'Ouest.

75 Department of Cooperation and Mutuality of the Ministry of Agriculture.

76 This is the French acronym which stands for "Centre National de Développement des Entreprises Coopératives". It was created by Decree No. 75/682 of Ocober 25, 1975 and charged with overseeing the activities of couperatives, a task which it started off in the Lékié Division as well as in the North West Province.

77 This latter reason would seem to be accurate in view of the fact that govemors of provinces were given power under Decree No. 78/485 of November 9, 1978, meant to reorganise the Ministry of Territorial Administration, to supervise the financial management of cooperatives implanted within their respective provinces and approve their accoumts. See Article 11 of that Decree. 
ments of the manager and other senior staff of a society were to be made by the Board of Directors with "the preliminary approval of the supervisory Minister"78, in practice the Department of Cooperation and Mutuality dominated not only the appointment process but also the making of all important decisions. This rendered the management organs of the cooperative structure under the 1973 Law, such as the Board, largely a matter of fiction since the manager was most often a civil servant who allowed little room for democratic decision-making and control.

Another very curious aspect of the 1973 Law was that it provided for the authorisation of pre-cooperatives 79 and also specifically provided that a decree shall define the conditions of its application, inser alia, concerning recording in the register of the Deparment of Cooperation and Mutuality, "public and registration, the obligations of members, the approval of managers, the election of directors and representatives, their powers and duties, rules and procedures of general meetings ... and liquidation of cooperative societies and their associations or federations"80. The said decree reproduced the terminology on precooperatives without defining it. And neither did any of its predecessors in which the term did not exist. The conditions for formations, approval and operation of pre-cooperatives were required to be the same as those for cooperatives under the law, except for registration which was required to be handled in a specific register. 81 Though the first such pre-cooperative seems to have been created in French-speaking Cameroon in 195782, this was not a nomenclature officially adopted in any of the legislation before the regulations applying the 1973 law. The rationale for its adoption would seem to be inherent in the fact that some cooperatives were not considered by the supervisory authorities as viable economic projects. For this reason, they were nomally approved to operate as pre-cooperatives at the discretion of the authorities for a trial period renewable once until their viability could be proved in which case they were then approved as cooperative societies. 83 Their status, however, entitled them to the same protection from the supervisory authorities as did the status of cooperatives.

But it would be totally dishonest to blame all the shortcomings of the 1973 legislation on the fact that most of its provisions were adopted in toto from previous legislation existing in the former East Cameroon which was more authoritarian in inclination than its counterpart in the former West Cameroon. The requirement that the intention to form a cooperative society be manifested in an instrument signed by ten persons was reproduced from section

78 See Law No. 73/15, Secrion 34 (2).

79 Id. Section 53.

80 Id. Section 9 (2).

81 See Decree No. 74/874 of October 29, 1974, Secrion 5 (1) and (2).

82 See Soho, op. cit. note 3, and Le Floch, op. cit. note 61 at p. 11. The name given to such pre-cooperatives was "centres de groupage".

83 See Decree No. 74/874, Secrion 6 (1) and (2). 
6 (2) (a) of the Southem Cameroons Cooperative Societies Law, $1955^{84}$, and so also was the requirement that members should not be less than 18 years of age85. Apart from these two provisions, however, there was almost nothing else adopted from the legislation of the former West Cameroon. It is in this sense that it is said that the attempt to unify the various pieces of legislation from the former Federated States in 1973 was a dismal failure. This failure of the attempt at unifying the law can be judged from the fact that whereas under the Southem Cameroons Law and the direction of various Registrars the Cooperative movement extended considerably in the former West Cameroon 86 , by 1988 cooperators and farmers alike had become so fed up with the 1973 Law that they wanted it repealed.87

Cooperators' and farmers' exasperation with the law derived from the fact that the applicaion of its provisions by the supervisory authorities had become a hindrance rather than an enchancement of progress in the cooperative movement. The Ministry of Agriculture did not heed their cry unil January 28, 1991. On that date the Minister of Agriculture signed a Declaration of Government Policy on Cooperatives and other Economic Groups in which is suddenly became "conscious of the insufficiencies of the control mechanisms and the participation of members which had until (now) prevailed in most cooperatives whose consequence was the lack of recognition on the part of members of existing structures"88. This policy statement was, therefore, the precursor of the reform of cooperative legislation that was concretised in 1992 due, on the one part to the economic crisis. On the other, the reforms were also precipitated by the major role played by informal groups in the agricultural sector and the potential which they represented for the economic development of the country. 89

\section{Recent Reform of Cooperative Legislation}

\section{The Chronology of Reform}

From the point of view of practical implementation of the Declaration, the Ministry of Agriculture immediately accelerated the work of a working-group which it had constituted in August 1990, under the auspices of the Division of Agricultural Projects, to begin work on drafting new legislation for cooperative societies and other economic groups. The

84 See op. cit. supra note 54 and text accompagnying it.

85 Decree No. 74/874, Section 11.

86 See Soho, op. cit. note 3 at p. 37.

87 See generally Ministère de l'Agriculture, Séminaire National sur le Mouvement Coopéraif au Cameroun: Recommandations, Yaoundé, Juillet 1988.

88 See generally Ministère de l'Agriculture, Déclaration de Politique sur les Coopératives et Autres 89 Id. Groupements Economiques, Yaoundé, 28 janvier 1991 at p. 1. 
objective assigned to that group was to elaborate new legislation that affimed the new policy orientation of government which now considered cooperatives and other economic groups as private and autonomous enterprises which did not depend on the public administration for the realisation of their respective activities. 90 Prior to this official policy declaration being made public, however, the Deprironent of Cooperation and Mutuality had been charged with the task of elaborating the new legislation. The draft that they urned in to the authorities demonstrated their aversion to any kind of reform that would strip them of their rights and privileges acquired in the implementation of the old law. As a preliminary step to setting up the working-group in the Division of Agricultural Projects, the Department of Studies and Projects, which was its predecessor, had already been directed to take over the job of reforming cooperative legislation.

Essentially, in view of the content of the government's policy declaration which gave individuals the possibility to choose freely between organising themselves either as classical forms of cooperatives on the Rochdale model91 or as other more flexible group structures, two draft laws were envisaged. There was a draft law on Economic Interest Groups and another on Cooperative Socielies and Common Initiative Groups.92 In drafting the texts, the working-group was guided by the fact that because cooperative societies have a variable share capital93 as well as limited liability for their financial obligations vis-à-vis third parties, the principles of law governing them should be more stringent than those goveming economic interest groups, which have unlimited liability. Consequently, the said principles had to be very precisely formulated so as to achieve the dual objective of allowing cooperatives full capacity to carry out business transactions and making them credit-worthy in the eyes of their members and third parties alike.

The first draft of the law by the working-group became available in December 199094 but could not go through to the National Assembly because of certain institutional issues that had not been resolves by the Ministry of Agriculture. A subsequent draft was made in August 1991 which included a statement of objects and reasons and was presented at a

90 Id. at p. 2.

91 Rochdale is the place near Manchester where the Equitable Pioneers first started a cooperative society in December 1844 based on what is now famously known as the Cooperative Principles. See Colombatin, M., Aspects et Problèmes Particuliers de la Coopération dans les Pays an Voie de Développement, Revue des Etudes Coopératives No. 145/146 (1966), Paris, IEC, at p. 243.

92 In view of the later evolution of things which took the law on Economic Interest Groups from the domain of competence of the Ministry of Agriculture to that of the Ministry of Industrial and Commercial Development, we are only concemed here with the law on Cooperative Societies and Common Initiative Groups, which as a matter of fact has already been promulgated whereas the former has not as of March 1993.

93 This is a consequence of their open door policy which is one of the cooperative principles.

94 See Müntener, H.H., Draft law on Cooperative Societies, Pre-couperatives and Producers Groups in Cameroon, Marburg, December 1990. 
cooperative law seminar that held in Yaounde from September 12 to 15, 1991. This seminar was a blue-print for future legislative reform because of the debate it engendered from the interested groups participating in it and the public authorities. Cooperators at the seminar pointed out that their problems with the old law arose principally from two sources. First, it was difficult for them to contend with the excessive control mechanism imposed by that law which exacerbated their problems of identifying with organisations existing under it. Secondly, there was a major obstacle in their understanding and implementing the legislation in that there was a lot of fragmentation between the law and the various regulatory texts implementing it since some were adopted long after the law itself had been promulgated. Because of these reasons, they needed comprehensive legislation which would be both a response to, and a catalyst for, a growing number of organisations wishing to adopt the cooperative form.

The seminar led to the Ministry of Agriculture adopting a draft of the text which was both comprehensive in nature and simple in language as well as style to meet the expressed aspirations of the cooperators. It seems rather unfortunate for the history of legal development in Cameroon that when that text was chanelled through the Prime Ministry for onward transmission to the National Assembly, it was rejected. The rejection was predicated on the fact that laws Cameroon are always written in skeletal form which poses the general principles, leaving it to the execurive power to define the rules that should guide their practical implementation. The reason that this is unfortumate for legal development and especially for the development of the cooperative sector is that given the usually low level of literacy of cooperators, it is difficult for them to deal with legislation that is fragmentary in character, requiring users to turn to several sources to be able to link the rules and principles together. On the other hand, particularly in the cooperative field, a survey of several countries with similar levels of development like Cameroon indicated that there was a growing tendency in this field for comprehensive legislation to be adopted that provides a source of predictable, certain and easily ascertainable rules.95 This notwithstanding, it was believed that the constitutional arguments raised by the Prime Minister in view of respecting the traditional domains reserved for the legislature and the executive, respectively, overrode the general concern of cooperators for comprehensiveness, certainty and predictability. On this basis another draft was made that respected the exigencies of the Prime Minister's office and it is

95 See in this regard Münkner, HH. / Penn, G.A., Revision of Couperative Legislation in Cameroon: Comments on previous Drafts and Third Draft Law on Cooperative Societies and Common Initiaive Groups in Cameroon / Decree of Application", Document prepared for USAID/Cameroon, Marbung/Jaoundé, February 1992 at pp. 2 et seq. Among legislation from other countries reviewed for comparison by the authors were ZATU No. AN VII-0035/FP/PRES ponant statut général des Groupements Pré-Coopéravifs et Sociétés Coopératives au Burkina Faso du 18 Mai 1990; the Singapore Cooperative Societies Act No. 15 of 1979 which contains very shor rules of implementaiion dealing with procedural matters; and the Tanzanian Cooperaive Societies Act, 1991. 
that draft which finally got promulgated on August 14, 1992 96 with its decree of application coming out on November 23, 1992.97

\section{The Content of the New Legislation: Positive Aspects}

The new law applies to cooperative societies and common initiative groups. The latter are a legal innovation in Cameroon though the law in this sense only formally recognises what already existed in practice in the informal sector. Common initiative groups under the law provide the legal framework for the economic operations of persons who have a need to group together in order to jointly underake economic activity. They are thus light structures suitable for people who do not have the same ambitions of creating common ownership as do those who are interested in forming cooperative societies. It is thus that a common initiative group can be formed by at least five persons 98 and a union of common initiative groups by two of those groups only99. Like cooperative societies, they also enjoy legal personality with limited liability100 and have the right to freely adopt their byelaws101. It should, however, be noted that the price to be paid by common initiative groups for enjoying limited liability implicit in the law is reduced credit-worthiness vis-à-vis bankers and other suppliers. This reduced credit-wortiness is a consequence of the more supple management structure that they are endowed with.102

One other characteristic of the law that needs highlighting at this preliminary stage is that unlike its predecessor, it adopts very specific provisions in regard to savings and credit cooperatives which are more commonly known as credit unions. In effect the law provides that savings and credit cooperatives have very specific objects which include promoting savings among their members, creating a source of capital which would permit them to accord loans to their members at moderate interest rates, and of fering their members other financial services which are complementary to savings and loans. 103 Furthermore, they can also engage in ordinary commercial banking operations provided they conform with the rules and regulations defined by the Ministry of Finance which govem such banks.104 Apart from these, a savings and credit cooperative can receive deposits from non-member

96 Op. cit. note 1.

97 Op. cit. note 1.

98 Law No. 92/006, Section 50 (1).

99 Id. Section 50 (2).

100 Id. Section 51 (2).

101 Id. Section 52 (1). There are, however, certain specific issues which the law provides must figure in the bye-laws. See Section 52 (2).

102 Id. Section 52 (3).

103 Id. Section 42.

104 Id. Section 48. 
users who cannot borrow from it ${ }^{105}$ and can also have its accounts audited by the union to which it is affiliated 106 unlike other kinds of cooperative societies which must employ an outsider to audit their accounts 107 . This liberty is tempered by the fact that each savings and credit cooperative society must have a credit committee of three to five persons appointed by its Board of Directors for a renewable term of one year, who are charged with granting loans to its members in accordance with its bye-laws. 108 Also, in their case, the responsibility of members for the obligations of the society with third parties is increased to five times the amount of subscribed share capital 109, while they cannot hold annual general meetings in the form of a meeting of delegates as provided in section 31 of the law for other kinds of cooperative socielies 110 . These are important safeguards which are provided by the law to guard against the unauthorised depletion of the capital resources of credit unions which can leave their members without much recourse against management.

Other than these very specific innovations in the 1992 law on cooperative socielies and common initiative groups, it is necessary to note that the law is definitely more liberal than its predecessor of 1973 on a variety of issues. To begin with, its liberal intent and focus are expressly and explicitly aff irmed not only in the provision that they are now private autonomous organisations which belong to their members and function without the intervention of the State111, but also in the one that the general meeting, rather than the supervisory Minister, is now the supreme organ of deliberation and decision-making for the cooperative society1 12. Moreover, the geographical boundaries of cooperatives no longer coincide with administrative boundaries 113; hence cooperative societies may extend as well as diversify activites. 114 Similarly, rather than just allow unions of cooperative societies and common initiative groups to form apex organisations only at the level of federations, the new law adds a new dimension by giving them the latitude to form confederations which may themselves become affiliated to intemational organisations with similar objectives. 115

With regard to membership, whereas one was required to be at least 18 years of a ge to be a member of a cooperative societey under the old law, the new law requires that membership be open to those who have at least attained legal majority. 116 This rather restrictive condi-

105 Id. Section 43.

106 Id. Section 47 (2).

107 Id. Section 39.

108 Id. Section 44.

109 Id. Section 45.

110 Id. Section 46.

111 Id. Section 2 (3) and 3.

112 Id. Section 15 (1).

113 Id. Section 5 (2).

114 Id. Section 4 (1).

115 Id. Section 73.

116 Id. Section 2 (1). 
tion for membership does not seem to detract from the other liberal criteria. This is evident, for instance, in the requirement that membership be governed by the provisions of the byelaws of each society which should not operate any discrimination based on ethnic, tribal, political or religious affiliation or even philosophical and trade union convictions. 117 This kind of "affirmative action" provision accords both with international norms and the preamble of the Cameroonian Constitution which grants equality to all citizens in economic matters. This provision in the new law on cooperative societies and common initiative groups is a novelty because its predecessor did not include it.

Funchermore, whereas under the 1973 law membership in a cooperative society was attested by a membership card issued by the Board of Directors 118 , the new law adheres strictly to the cooperative principle of keeping an open door so that there would be no constraints on the variation of membership which may be inherent in a discretion of a Board to decide whether or not to issue a card to a particular postulant. A further incentive given to people wishing to become members of a cooperative society is that if a member voluntarily withdraws from membership or is expulsed he would be reimbursed the amount due on his subscribed shares, taking into account any appeciation or depreciation that may have affected the assets of the organisation during his membership. 119 Another supple condition is that the minimum number of members required to form a cooperative society has now been reduced to seven 120 instead of ten in the former law.

Whereas certain kinds of terminology have disappeared from the structure of cooperative societies 121 , certain pertinent innovations are now apparent in the structure of the management organs envisaged under the new law. Thus, the annual general meeting which under the old law was required to be convened at least once a year within six months following the end of the financial year122, not has to be convened not later than three months following the close of the financial year 123. Furthermore, the supervisory Ministry no longer has the powers to convene a general meeting, appoint a manager 124, decide on whether or not it is proper for a cooperative society to invest 125 , give its fiat to an amalgamation or division nor its approval of a proposed voluntary winding-up. Also, the law

\section{Id. Section 2 (2).}

118 See Law No. 73/15, Section 13.

119 See Law No. 92/006, Section 13 (1).

120 Id. Section 9 (1).

121 These include things such as pre-cooperatives, primary cooperaive societies and cooperative socienies with unlimited liability.

122 See Law No. 73/15, Secrion 23 (2).

123 See Law No. 92/006, Section 17.

124 Only the Board of Directors has the right now to appoint a manager, if the need arises, and delegate some of its powers of management to him. See Law No. 92/006, op cit., Section 22 (2).

125 The necessity for a cooperative society to invest can now only be determined by the General Meeting in virtue of Seclion 37 of Law No. 92/006. 
now provides for the creation of a Supervisory Committee which, unlike its predecessor, the Technical Committee whose duties under the old law were limited to advising and assisting the Board of Directors, has extensive duties ranging from regularly controlling the management of a cooperative society and inventories to drawing up reports for general meetings and carrying out inquiries 126.

In the case of liquidation, a Verification Committee is supposed to be created which will assist the liquidator in making an inventory prior to the beginning of the liquidation. The membership of the Verification Committee, where the need for one arises, is supposed to be made up of an equal number of members and creditors of the organisation of liquidation. 127

With regard to financial issues affecting cooperative societies and other organisations under the new law, it should be noted that whereas under the law of 1973 there was some precision as to the maximum amount of interest that could be paid on each subscribed share128, the new law just vaguely provides that the interest on shares shall be limited129. However, this imprecision in the new law is illusory because it goes on to provide that the interest rate will be determined on a yearly basis by the annual general meeting 130 , commensurate with the interest rate fixed by commercial banks on long-term deposits131. Especially for savings and credit cooperatives which, as has been observed earlier, can engage in commercial banking activites by complying with rules and regulations fixed by the Ministry of Finance132, this provision puts them at par with the banks and protects them from the possibility of members holding them liable for falling interest rates where the phenomenon is generalised. Furthermore, reserves have now been made a statutory obligaion to be deducted annually from profits at the rate of $20 \%$ till the reserve funds is equal in amount to the subscribed share capital (and not the equity capital as provided in the English version of the law).133

In respect of the transformations that may occur during the life of a cooperative society, the 1992 law also introduces some very important innovations. It is in this light that cooperative societies can form apex organisations ranging from unions to confederations which are themselves allowed to join intemational organisations whose objectives are similar to theirs. In the case of amalgamations and divisions, whereas the 1973 law envisaged that

126 See Law No. 92/006, Sections 26 et seq.

127 Id. Section 72 (2).

128 See Law No. 73/15, Section 16 (4) which put the interest at $6 \%$ per annum.

129 See Law No. 92/006, Section 11.

130 Id. Section 18.

131 Id. Section 35.

132 See op. cit. supra note 104 and text accompagnying it.

133 See Law No. 92/006, Section 34 (3). 
where there was an amalgamation of cooperative societies the new entity resulting therefrom should simply assume all the assets and liabilities of the former entities 134 , the law of 1992 allows the extraordinary general meeting convened to decide on an amalgamation of division to also make a decision as to what should happen to the assets and liabilities of the former entity or entities. 135 This new provision cures an aberration which under the old law required that if a cooperative society had larger legal reserves and amalgated with one whose reserves were lower, the members of the former should lose the beneficial interest they were entitled to because of the enhanced value of their shares in their former entity. 136 Naturally, such a provision made societies reluctant to amalgamate with one another where there was no short-term benefit for hard work. Moreover such a modification of the structure of a cooperative society did not really guarantee any rights that had already ancrued to existing members since the supervisory Minister was the only one who possessed authority to define measures necessary for protection of the interests of members and creditors alike.137 He could even appoint a liquidator, which was an oddity because a liquidator normally has no place in an amalgamation. 138

Now under the new law, both members and creditors alike are better protected. First the measures necessary to protect their interests are no longer left to the discretion of the suvervisory Minister. In the case of creditors they are required to be informed at least one month prior to the holding of an extraordinary general meeting to decide on an amalgamation or division, especially with regard to the possible financial repercussions of the intended amalgamation or division 139 so that they may take steps to protect their interests by even objecting to it unless their debts are realised immediately.140 They must also notify this to the Registry for cooperative societies and common initiative groups. 141 Members of an organisation involved in an amalgamation or division, on the other hand, may withdraw their membership from the new organisations resulting from either event 142 if they signify this in writing, at the latest, to the extraordinary general meeting convened to decide on the operation. 143

Furthermore, although all legislation conceming cooperatives from the colonial era has provided for the eventuality of their going out of existence, the 1973 law particularly provided

134 See Law No. 73/15, Section 45 (3).

135 See Law No. 92/006, Section 63 (2).

136 op. cit., note 134.

137 Law No. 73/15, Section 45 (2).

138 Id.

139 Law No. 92/006, Section 64 (1).

140 Id. Section 65 (2).

141 See Decree No. 92/455/PM, Section 27 (2).

142 Law No. 92/006, Section 65 (1).

143 Decree No. 92/455/PM, Section 26. 
for two ways through which a dissolution could be effected. The one was voluntary and the other was due to a decision taken by the sopervisory Minister in cases where the cooperative had either violated the provisions of laws, regulations or its bye-laws, or where its financial situation did not allow it to fulfill its obligations vis-à-vis the State and others, or carry out its normal activities. 144 In addition to these two modes of going out of existence, the 1992 law has now added a third, which consists in a court of law deciding to dissolve any of the organisations governed by this law if it has violated laws, regulations or provisions of its bye-laws and has not redressed the situation within one year after such violation, or where it is bankrupt, or where it has lost over three quarters of its share capital and this has not been replenished at the end of the following financial year, or again where it has ceased all of its main regular acitivites for two consecutive years.145

This new provision now reduces the role which the Ministry of Agriculture can exercise through the Registration Office merely to cases where there has been the non-deposit of financial documents and mandatory reports for a consecutive period of two years, or where the number of members in the cooperative society has fallen below the statutory minimum of seven.146 But even in these situations, the power to exercise ex-officio dissolution by the administrative agency is required to be used with the greatest circumspection. In effect the law requires the administrative agency to notify the default to the cooperative society and then only proceed to carrying out its dissolution of nothing has been done within two months after the notification to redress the situation. 147

Apart from this provision which safeguards the acquired and rested rights of a cooperative society or other organisation created under the new law, whether dissolution is voluntary, ex officio or decided upon by a competent court of law, the party making such decision is entitled to appoint a liquidator. Unlike under the former law where the liquidator exercised all of his duties under the sole control of the Supervisory Minister 148, under the new law he is entitled to furnish an opening balance sheet, a three-monthly report, a final balance sheet and a final report of his activities when they come to an end and only notify the administrative agency in charge of registration with copies of these documents. 149 Moreover, his duties are supposed to be carried out with a Verification Committee composed of two representatives of the organisation under dissolution on the one hand, and two representatives of the creditors on the other, all of whom are to be appointed by the interested parties at most twenty one days after notification of the decision to dissolve.150 Also, in case of a

144 See Law No. 73/15, Seciion 49.

145 Law No. 92/006, Section 69.

146 Id. Section 70 (1).

147 Id. Section 70 (2).

148 See Decree No. 74/874, Secrion 70.

149 See Decree No. 92/455/PM, Section 31.

150 Id. Section 32. 
dissolution, the law now provides that the interests of creditors should be protected in the same manner as those of the creditors of a commercial company that has gone into liquidation. 151 This provision is quite important because in principle, it ensures that the claims of secured creditors are either superior to, or rank pari passu with those of any administrative agency. In normal cases, such an administrative agengy would be the department of taxation. However, since the law itself provides that cooperative societies are exempt from corporate tys by virne of section 3 of the Geneal Tax Code152, in practice, this provision should mean that cooperative societies and other organisations under the law have an increased power of borrowing since secured creditors would feel safer lending to them in the absence of the much vaunted "privilège du tressor".

Two further features of the new law need highlighting as well at this juncture. The first is that it takes away all registration formalities from the D-parment of Cooperation and Mutuality and confides them to a Registry which, although dependent on the Ministry of Agriculture like the former, has only the duty of ensuring that the provisions of the law and its implementating decree are met with. 153 Consequently, the Registry's specific duties linked with the keeping of the register of cooperative societies, common initiative groups and their unions are incompatible with any other duties linked to the development and promotion of these organisations. The other aspect of the law that needs highlighting is that unlike its predecessor which required existing organisations at the time of its promulgation to continue functioning, the 1992 law requires cooperative societies, precooperative societies and their unions which had their head offices in Cameroon at the date of its promulgation to re-register within eighteen months of that date. 154 Thus where a cooperative society fails to re-register within this time-limit, power is given to the Registry to immediately and automatically dissolve that society and appoint a liquidator to take care of the dissolution. This provision seems quite draconian but the necessity for it arises from the fact that far too many cooperative societies and unions of cooperative societies existing at the time of promulgation of the law exist only as hams and mere shells, sometimes imployed to deprive the farmer of the fruits of his produce. The fact is evidenced by the number of trips the various Ministers of Commercial and Industrial Development have had to make within the past couple of years to pay arrears owed by cooperative societies and other exporters of produce to farmers.

The provision, therefore, serves the dual purpose of permitting the registry to make an inventory of existing cooperative societies that are salvagable and to make sure that they conform with the prescription of the new law with regard to membership, structure and

151 Law No. 92/006, Section 72 (1).

152 Id. Section 77.

153 Id. Section 75.

154 Id. Section 83. 
geographical organisation. It is now possible for the organisations concemed by this provision to deposit their files for re-registration as soon as the Registry is set up because in practice the limitation period should not begin to $\mathrm{nm}$ until one exists. If this is done and the Registry does not notify its refusal to register within two months of when the file is deposited then the organisation is presumed to have been registered with effect from the date of deposit of its file. 155

\section{The Content of the New Legislation: Short-comings and Potential Problems}

Generally, the 1992 law on cooperative societies and common initiative groups is more liberal and less interventionist that its 1973 predecessor which govemed only cooperative societies. Some of its essential attributes, as already pointed out, include the desire to encourage an equitable flow of infonnation in societies with large membership or cumbersome geographical features 156 , transparence in record-keeping157 and rigourous management 158, and the freedom given to federations and confederations to choose the form of their organisation 159 , inter alia. The a priori impression from reading the law is an affirmed intention to devolve responsibility and accountability on the registry.

Though liberal, however, the law is far from perfect. On a preliminary note, one of its essential flaws is the exceptionally poor quality of the English version of the law which results from a literal translation from the French text. That version finds itself ridden with a lot of ambiguities which may hinder the proper interpretation and application of the text by mere cooperators not trained in the arcane use of legal tenninology. Thus, for instance, when the law provides that a cooperative society shall be an organisation defined in a particular manner which shall lay down rules governing, among other things, "the equitable distribution of its capital" 160 there is no doubt in the ambiguity of the phrase. This is because if a cooperative society distributes its capital, even equitably, it is doubtless that the capital will either be eroded, depleted or cease to exist. In either of these situations, though the law does not provide for a nominal share capital for cooperative societies, the cooperative society may no longer have a raison d'être if its substratum disaypears to the point where members do not make any further effort to subscribe new capital. Another translation problem concerns reserves, which have now been made a statutory obligation to be deducted annually from profits at the rate of $20 \%$ till the reserve fund is equal in amount to the

155 Id.

156 Id. Section 33.

157 Id. Section 61 .

158 Id. Section 26 et seq.

159 Id. Section 74.

160 Id. Section 8. 
subscribed share capital and not the equity capital as provided in the English version of the law.161

Moreover, since unlike under the Companies Ordinance applicable in the case of companies in the former West Cameroon162, the new cooperative law does not provide for specific liability in the case of a reduction of members which might entail a reduction of capital. It is, thus, to be feared that a literal interpretation of this provision in section $\mathbf{8}$ of the law may augur poor financial health for cooperative societies in Cameroon.

With regard to membership, whereas one was required to be at least 18 years of age to be a member of a cooperative society under the old law, the new law requires that membership be oben to those who have at least attained legal majority. 163 Used in this context, the phrase "legal majority" is susceptible to causing confusion. This is because in Cameroon, legal majority varies according to whether one is considering criminal responsibility, the capacity to marry or the right to vote. The phrase is therefore vague in this context and should have been subject to more precision even in the decree of application.

The law also clearly makes the services of the new registration department free of charge to users and forbids any direct or indirect remuneration of workers of the department, under pain of criminal liability in accordance with specific provisions of the Penal Code. 164 This provision is a direct conflict of interest provision which forbids an administrative agent to carry out his duties only if he believes that he is going to receive direct or indirect recompense from the person seeking to benefit from the service. However, in view of the fact that it is quite rampant in the Cameroonian public administration to perceive one's duty as a favour to the user for which recompense is due, serious questions still arise about the enforceability of such a well-intentioned provision.

The provision that existing cooperatives, pre cooperatives and unions should be re-registered under the new law serves the dual purpose of permitting the registry to make an inventory of existing cooperative societies that are salvagable and to make sure that they conform to the prescriptions of the new law with regard to membership, structure and geographical organisation. Though necessary, however, it is clear from a strictly legal standpoint that the provision violates the principle of non-retroactivity of laws which seems essential for the safe guard of acquired and vested rights.

161 See Law No. 92/006, Section 34 (3).

162 See Companies Ordinance, CAP 37 of Laws of the Federation of Nigeria, 1958, Section 122.

163 Law No. 92/006, Section 2 (1).

164 Id. 
Without being exhaustive, these are just a few examples of the flaws (some of which are in the original French text while others are inherent in the English text of the law) that create ambiguity and cause confusion in understanding. On the practical side, the implementation of the new law poses quite a number of problems because of the lack of means to disseminate the provisions of the new law to the already handicapped cooperative sector. It is also to be regretted that some nine months after the promulgation of the law on cooperative societies and common initiative groups the registry, which is the key piece in the implementation of the new legislation, is still not in operation.

In addition to the possibility of inefficiency in the implementation of the law, the spectre of the much dreaded Decree No. 78/485 of 1978 still looms large over the assets and property of cooperative societies and other kindred organisations. This decree, as has already been observed 165, grants large powers to administrative officers such as Govemors, Prefects and Sub-Prefects over the internal affairs of cooperative socielies. With regard to this specific issue, however, it must be noted that the argument that decree No. 78/485 cannot be repealed by the implementing decree of the new law smacks of too much technicality and formalism, but is not without merit. In effect, by virtue of a French administrative law principle known as the notion of "parallélisme de forme", that decree can only be repealed by another presidential decree reorganising the Ministry of Territorial Administration. The organigram is out, but the decree is not repealed. This, however, does not gainsay the real possibility of abuse of the provisions of the decree because unless it is repealed, it continues to have vitality as well as permit administrative officers to interfere in the internal affairs of cooperative societies though they are autonomous private bodies belonging to their members who manage, fund and, in principle, control them.166

There is no doubt that the specific provision of that decree relating to cooperative societies will sooner or later be repealed. What is doubtful is that with the continuous insistence on the fragmentation of legislation inherent in that eventual repeal, there would be enough will and resources to disseminate its repeal to cooperators so as to allay the possibility of their being abused by unscrupulous administrative officers. This, therefore, calls for a lot of vigilance on the part of the registry which should assume the function of "guardian ad litem" of cooperative societies and common initiative groups in this regard.

\section{Conclusion}

The new legislation on cooperative socielies and common initiative groups is now available along with its implementing regulations. This brief review of the evolution of legislation

165 See supra note 77 and text accompagnying it. 166 Law No. 92/006, Section 3. 
essentially with regard to the forner type of organization has revealed that cooperative legislation started out with a liberal intent on both sides of the colonial divide and meant to encourage economic development through what were mostly rural agricultural organizations. However, like legislation in most other areas of activity, it soon fell prey to political xenophobia even prior to independence. Building on this xenophobia and perhaps with the help of the dogged policies of planned liberalism, self-reliant development and their progeny, communal liberalism, govenment intervention in the regulation and development of cooperative activity soon bedame asphyxiating.

The new legislation that is now available was originally conceived to encourage the development of a new breed of grassroots cooperative organisations by switching from prescriptive standards in regulation to performance standards. The easiest way this could have been achieved would have been through the enactment of comprehensive legislation. But in conformity with the adage that old habits die hard, this was resisted by the execulive arm of govemment. One thing that stands to the credit of the new legislation, however, is that it is now possible to create cooperative societies in all areas of human activity. But at a time when the new law is coming into force, it is still open to question now is whether cooperatives in Cameroon shall under it become truly competitive free market tools that would enhance economic development. Though because of the lack of empirical data on its implementation it is still premature to respond either affirmatively or regatively to this burning question, it is to be noted that this is possible of the government continues to play an important role not as a centralised decision-maker but as a promoter and coordinator of policies and institutional structures for growth. On the other hand, significant insignia exist that lead us to have serious misgivings in this regard. Among these, is the continuing practice of govemment to fix prices for primary produce in the agricultural sector as well as fix licensing criteria for buyers, respect for which does not seem to be legion. Enough evidence exists that points to the fact that liberalisation is incompatible with monopolistic tendencies and this is why it should be a source of satisfaction that certain contractual conditions granting monopolies to cooperatives in the North-West and Western provinces in arabica coffee marketing have been lifted during this 1992/93 coffee campaign season.

As pointed out earlier, there still exist certain administrative constraints, notably inherent in decree No. $78 / 485$, that may lead to the conclusion that little benefit would be reaped from the recent legislative reforms. But it is doubtful that these are enough insignia for despair. The very fact that the law exists in its present form is in itself sufficient sign of hope. 


\title{
ABSTRACTS
}

The Limits of Human Rights: Some Aspects of the Ghanaian Fourth Repubiican Constitution in Perspective

\author{
By Kofi O. Kufuor
}

This paper examines some of the provisions relating to human rights under Ghana's Fourth Republican Constitution. The underlying theme of this analysis is a critical look at civil and political rights, and economic and social rights. The objective in this respect is to discuss the extent of the individuals' rights guaranteed under the Constitution.

Although this paper does not have as its specific methodology a comparison between the constitutional provisions on the one hand and the Intemational Covenant on Civil and Political Rights and the International Covenant on Economic, Social and Cultural Rights on the other, both Covenants have served as "yardsticks" in the appraisal of the human rights provisions of the Ghanaian Constitution.

\section{The Evolution of Cooperative Legislation in Cameroon}

By Godfred A. E. Penn and Wawa A. Ngenge

On the background of the current difficulies of Cameroon's economic development process, the Govemment of Cameroon decided to strengthen the role, among others, of cooperative societies representing private economic effort. A respective Government Policy Declaration of early 1991 was followed by the elaboration of a new legislation on cooperatives and common initiative groups which finally entered into force in 1992. The article reviews the historical roots of the law of cooperatives in both former parts of Cameroon and critically assesses the new legislation against this background. The authors conclude that, despite some shortcomings in contents and language, the new law constitutes a more liberal approach towards such private groups than its predecessors and thus represents a sign of hope in today's economic situation. 